\title{
Tablet Coated Particle Dosage Form
}

National Cancer Institute

\section{Source}

National Cancer Institute. Tablet Coated Particle Dosage Form. NCI Thesaurus. Code C60997.

A tablet composed of a conglomerate of particles that contains active and/or inert ing redient(s) that have been individually covered with a coating. 